\section{Resistance of Watermelon Seedlings and Fruit to the Fruit Blotch Bacterium}

\author{
D.L. Hopkins, C.M. Thompson, and G.W. Elmstrom \\ University of Florida, Institute of Food and Agricultural Sciences, Central \\ Florida Research and Education Center, 5336 University Avenue, Leesburg, \\ FL 34748
}

Additional index words. Citrullus lanatus, bacterial fruit blotch, Pseudomonas pseudoalcaligenes subsp. citrulli, resistant cultivars

\begin{abstract}
Seedlings of 22 watermelon [Citrullus lanatus (Thunb.) Matsum. and Nakai] cultivars and two plant introductions were screened in the greenhouse for resistance to the fruit blotch bacterium. There were significant differences in disease severity among cultivars, but no cultivar was immune to the bacterium. In field tests, fruit of 18 commercial cultivars were inoculated individually or became infected naturally from diseased foliage. Cultivars with relatively resistant fruit included 'Sugar Baby', 'Jubilation', 'Mirage', 'Calsweet', 'Crimson Sweet', 'Royal Sweet', and 'Sangria'. The more susceptible cultivars generally had a light-colored rind. Cultivar level of resistance to bacterial fruit blotch may not be sufficient under conditions conducive to severe disease development.
\end{abstract}

In Spring 1989, a new fruit rot disease was observed in commercial watermelon fields in Florida, and, as the watermelon season progressed, the disease was observed in other southeastern, mid-Atlantic, and midwestem states (Hopkins, 1989; Latin and Rane, 1990). In some fields, especially in Florida and South Carolina, losses were as high as $80 \%$ of the total marketable fruit. Symptoms on the fruit begin as small, water-soaked areas that rapidly enlarge to dark-green, water-soaked lesions several centimeters in diameter with irregular margins. Initially, lesions do not extend into the flesh of the melon; however, as the lesions age, the melon's surface often cracks and fruit decay follows, oftenduring shipment. A similar disease was reported in Australia and Guam, where it was named "fruit blotch" (Wall and Santos, 1988). The fruit blotch bacterium also produces symptoms on watermelon leaves. Initial symptoms on seedlings consist of water-soaking of lower cotyledon and leaf surfaces, followed by necrotic lesions. These lesions have irregular margins and chlorotic halos and frequently occur along major leaf veins. Foliar symptoms in the field are not distinctive and may be inconspicuous to the grower.

The bacterium that causes fruit blotch in Guam (Wall and Santos, 1988) and the eastern United States (Latin and Rane, 1990; Somodi et al., 1991) is similar, but not identical, to a bacterium that caused disease on certain watermelon plant introduction (PI) seedlings in

Received for publication 9 Dec. 1991. Accepted for publication 21 Sept. 1992. Florida Agricultural Experiment Station Journal Series no. R-02015. The cost of publishing this paper was defrayed in part by the payment of page charges. Under postal regulations, this paper must therefore be hereby marked advertisement solely to indicate this fact.
Georgia (Webb and Goth, 1965). This bacterium was identified as Pseudomonas pseudoalcaligenes subsp. citrulli (Schaad et al., 1978), but in 1992 its taxonomic classification was changed to Acidovorax avenue subsp. citrulli (Willems et al., 1992). Commercial watermelon cultivar seedlings varied significantly in their resistance to this bacterium (Goth and Webb, 1981). In an earlier study, two PIs (PI 295843 and PI 299378) were resistant to $P$. pseudoalcaligenes subsp. citrulli and were considered sources of resistant genes (Sowell and Schaad, 1979). The fruit blotch bacterium from Guam caused smaller lesions on 'Crimson Sweet' than on 'Glory', an early maturing Charleston Graytype watermelon (Wall and Santos, 1989). The present study evaluated the resistance of seedlings and fruit of 22 commercial watermelon cultivars and the above PIs to Floridian fruit blotch strains WFB89-1 and WFB89-2.

The fruit blotch strains were isolated in Florida from commercial watermelons in Spring 1989, grown on nutrient agar for $48 \mathrm{~h}$, and then washed from the agar's surface with sterile, deionized water. Using a spectrophotometer, bacterial suspensions were adjusted to $\mathrm{A}_{600 \mathrm{~nm}}=0.25$ and diluted 200 -fold with sterile water $\left(10^{5}\right.$ to $10^{6}$ colony forming units/ $\mathrm{ml}$ ) for inoculation. Seedlings were inoculated either by rubbing the cotyledons of 2-week-old plants with an inoculum-saturated cotton gauze pad (swabmethod) or by misting the seedlings with inoculum until runoff using an atomizer. After inoculation, seedlings were placed in a moist chamber for $72 \mathrm{~h}$ and maintained in a greenhouse to observe symptom development. Disease incidence was rated 14 days after inoculation using a scale based on symptom appearance: $0=$ no symptoms: $1=$ small, restricted lesions, $<20 \%$ of the cotyledon necrotic; 2 = necrotic lesions with chlorosis, $20 \%$ to $50 \%$ of the cotyledon necrotic; and $3=$ large spreading lesions, $>50 \%$ of the cotyledon necrotic.The experiments were randomized block designs with four replications of 10 seedlings each.

A field test consisting of 18 watermelon cultivars was begun on 10Aug. 1989. Seedlings were planted in plots that consisted of one 7.6$\mathrm{m}$-long row with six hills. Test plots were arranged in randomized complete blocks with three replications. Five weeks after planting, the first plant in each plot was inoculated with the fruit blotch bacterium. Bacterial suspensions, as described above, were sprayed on the foliage until run off using a backpack sprayer with a manual pump. Allplants wereinoculated in the late afternoon. Foliar symptoms were rated 2 weeks after inoculation on a scale of 0 $=$ no symptoms, $1=$ less than $50 \%$ of the inoculated foliage necrotic, $2=$ greater than $50 \%$ of the inoculated foliage necrotic, and 3 $=$ greater than $50 \%$ of the inoculated foliage necrotic and spread of symptoms to noninoculated foliage. On 2 Oct., four fruit (10 to 20 days postanthesis in age) per replication were inoculated (sprayed) with bacterial suspensions until runoff using an atomizer. On 18 Oct., another four fruit (25 to 35 days postanthesis in age) per replication were inoculated. Three weeks after inoculation, the percentage of inoculated fruit that developed fruit blotch symptoms was determined.

On 19 Mar. 1990, the same 18 cultivars were planted in similar field plots. This test differed from the first field test in that plants in the third hill in each row were inoculated once, 3 weeks after planting. The percentage of fruit that developed fruit blotch symptoms was determined at harvest.

All cultivar and both PI seedlings developed symptoms after inoculation; however, there were significant differences in disease severity. In an experiment comparing the resistance of the PIs with that of selected commercial cultivars, the PIs were as susceptible

Table 1. Comparison of watermelon cultivars and plant introductions (PIs) for seedling resistance to bacterial fruit blotch in greenhouse inoculation tests.

\begin{tabular}{|c|c|c|}
\hline \multirow[b]{3}{*}{ Entry } & \multicolumn{2}{|c|}{ Severity rating $^{z}$} \\
\hline & \multicolumn{2}{|c|}{ Type of inoculation } \\
\hline & $\mathrm{Swab}^{y}$ & Mist $^{x}$ \\
\hline Sugar Baby & $1.2 \mathrm{a}$ & $2.2 \mathrm{bc}$ \\
\hline Jubilee & $1.5 \mathrm{a}$ & $1.2 \mathrm{a}$ \\
\hline Congo & $1.7 \mathrm{ab}$ & $2.0 \mathrm{ab}$ \\
\hline Crimson Sweet & $1.7 \mathrm{ab}$ & $2.0 \mathrm{ab}$ \\
\hline Queen of Hearts & $2.0 \mathrm{bc}$ & $1.5 \mathrm{ab}$ \\
\hline Florida Giant & $2.7 \mathrm{~cd}$ & $2.7 \mathrm{c}$ \\
\hline PI 295843 & $2.5 \mathrm{~b}-\mathrm{d}$ & $1.5 \mathrm{ab}$ \\
\hline PI 299378 & $3.0 \mathrm{~d}$ & $1.5 \mathrm{ab}$ \\
\hline
\end{tabular}

${ }^{2}$ Disease severity was rated 14 days after inoculation using a scale based on cotyledon symptoms: $0=$ no symptoms, $1=$ less than $20 \%$ necrotic, $2=20 \%$ to $50 \%$ necrotic, and $3=$ greater than $50 \%$ necrotic. Mean separation in columns by Duncan's multiple range test, $P=0.05$.

${ }^{\gamma}$ Two-week-old plants were inoculated by rubbing cotyledons with an inoculum-saturated cotton gauze pad.

${ }^{x}$ Seedlings were misted with inoculum until runoff using an atomizer. 
to fruit blotch as the cultivars (Table 1). The PIs seemed to be more susceptible after swab than mist inoculation. Because PI seeds were scarce, the PIs were not included in replicated field tests. In a 1990 single-row observational test, however, fruit blotch symptoms developed on the inoculated fruit of both PIs.

In seedling tests evaluating 21 of the cultivars, there was variability between the two inoculation methods, but the relative cultivar ratings were generally similar (Table 2). 'Charlee' was an exception in that it was more resistant to mist than swab inoculation. 'Crimson Sweet', 'Early Jubilee', 'Jubilee', 'Sangria', and 'Sugar Baby' were the most resistant cultivars at seedling stage.

In the Fall 1989 test, foliar symptoms developed on all cultivars after inoculation (Table 3). Variability in symptom severity was high among plots; therefore, there were no significant differences among cultivars. Disease spread from inoculated hills was limited. After individual fruit inoculation, symptoms failed to develop in 'Crimson Sweet', 'Early Jubilee', 'Sangria', and 'Sugar Baby'. Symptoms developed most frequently in 'Mickylee', 'Crimson Tide', and 'Minilee' fruit. Few noninoculated fruit of any cultivar developed symptoms.

After foliar inoculation in the Spring 1990 test, leafspot symptoms spread rapidly to the noninoculated plants, and, by anthesis, all plants had developed foliar symptoms. The fruit blotch symptoms first were observed on the more susceptible cultivars $\approx 2$ weeks postanthesis. Incidence of fruit symptoms varied among cultivars. 'Sugar Baby' had no symptoms, while $<20 \%$ of the fruit of eight other cultivars was infected (Table 3). Symptoms developed most frequently on 'Mickylee', 'Charlee', 'Charleston Gray', 'Charleston Gray 133', and 'Prince Charles'.

'Garrisonian' was reported to be immune (Goth and Webb, 1981) and Congo resistant (Sowell and Schaad, 1979) to P. pseudoalcaligenes subsp. citrulli. In our study, 'Garrisonian', 'Congo', PI 295843, and PI 299378 seedlings were susceptible to fruit blotch. These inconsistent results indicate that the two bacterial strains probably are different; however, environmental factors could also cause this inconsistency. In addition, P. pseudoalcaligenes subsp. citrulli differed from the fruit blotch bacterium in that the former was a serious problem on watermelon only in the greenhouse, not in the field, and did not cause ahypersensitive reaction in tobacco (Nicotiana tabacum L.) (Somodi et al., 1991).

While cultivar seedlings differed in fruit blotch resistance, none was immune. It was evident from the field test results that none of the cultivars was sufficiently resistant to limit the spread of fruit blotch among plants in the field after rainfall or overhead irrigation. Some fruit were more resistant to fruit blotch than others. Fruit resistance seemed to be related to rind color. The most susceptible fruit generally had a light-green rind typical of 'Charleston Gray'. The most resistant fruit tested was
Table 2. Comparison of watermelon cultivars for seedling resistance to bacterial fruit blotch in greenhouse inoculation tests.

\begin{tabular}{|c|c|c|}
\hline \multirow[b]{3}{*}{ Cultivar } & \multicolumn{2}{|c|}{ Severity rating' } \\
\hline & \multicolumn{2}{|c|}{ Type of inoculation } \\
\hline & Swab $^{y}$ & Mist" \\
\hline Jubilee & $1.0 \mathrm{a}$ & $1.7 \mathrm{a}-\mathrm{c}$ \\
\hline Sugar Baby & $1.2 \mathrm{ab}$ & $2.0 \mathrm{a}-\mathrm{d}$ \\
\hline Sangria & $1.5 \mathrm{a}-\mathrm{c}$ & $1.2 \mathrm{a}$ \\
\hline Crimson Sweet & $1.7 \mathrm{a}-\mathrm{d}$ & $1.5 \mathrm{ab}$ \\
\hline Early Jubilee & $1.7 \mathrm{a}-\mathrm{d}$ & $1.5 \mathrm{ab}$ \\
\hline Royal Sweet & $2.0 \mathrm{~b}-\mathrm{e}$ & $2.0 \mathrm{a}-\mathrm{cl}$ \\
\hline Charleston Gray & $2.0 \mathrm{~b}-\mathrm{e}$ & $2.5 \mathrm{c}-\mathrm{e}$ \\
\hline Royal Jubilee & $2.0 \mathrm{~b}-\mathrm{e}$ & $2.5 \mathrm{c}-\mathrm{e}$ \\
\hline Prince Charles & $2.0 \mathrm{~b}-\mathrm{e}$ & $2.2 \mathrm{~b}-\mathrm{e}$ \\
\hline Garrisonian & $2.0 \mathrm{~b}-\mathrm{e}$ & $2.7 \mathrm{de}$ \\
\hline Alsweet & $2.0 \mathrm{~b}-\mathrm{e}$ & $2.5 \mathrm{c}-\mathrm{e}$ \\
\hline Mirage & $2.2 \mathrm{c}-\mathrm{f}$ & $2.5 \mathrm{c}-\mathrm{e}$ \\
\hline Jubilation & $2.2 \mathrm{c}-\mathrm{f}$ & $2.5 \mathrm{c}-\mathrm{e}$ \\
\hline Charleston Gray 133 & $2.2 \mathrm{c}-\mathrm{f}$ & $2.2 \mathrm{~b}-\mathrm{e}$ \\
\hline Mickeylee & $2.2 \mathrm{c}-\mathrm{f}$ & $3.0 \mathrm{e}$ \\
\hline Royal Windsor & $2.5 \mathrm{~d}-\mathrm{f}$ & $2.5 \mathrm{c}-\mathrm{e}$ \\
\hline Charlee & $2.5 \mathrm{~d}-\mathrm{f}$ & $1.5 \mathrm{ab}$ \\
\hline Minilee & $2.5 \mathrm{~d}-\mathrm{f}$ & $3.0 \mathrm{e}$ \\
\hline Congo & $2.5 \mathrm{~d}-\mathrm{f}$ & $2.5 \mathrm{c}-\mathrm{e}$ \\
\hline Crimson Tide & $2.7 \mathrm{ef}$ & $3.0 \mathrm{e}$ \\
\hline Florida Giant & $3.0 \mathrm{f}$ & $3.0 \mathrm{e}$ \\
\hline
\end{tabular}

${ }^{2}$ Disease severity was rated 14 days after inoculation using a scale based on cotyledon symptoms: $0=$ no symptoms, $1=$ less than $20 \%$ necrotic, $2=20 \%$ to $50 \%$ necrotic, and $3=$ greater than $50 \%$ necrotic. Mean separation in columns by Duncan's multiple range test, $P=0.05$.

${ }^{8}$ Two-week-old plants were inoculated by rubbing cotyledons with an inoculum-saturated cotton gauze pad.

Seedlings were misted with inoculum until runoff using an atomizer.

'Sugar Baby', which has a solid dark-green rind. Fruit with light- and dark-green stripes, such as 'Sangria' and 'Crimson Sweet', were also more resistant than the light-green cultivars. Based on observations of fruit blotch incidence in commercial fields in Florida, however, resistance in diverse watermelon cultivars may not be sufficient to produce them successfully under conditions conducive to severe disease development. Losses as high as $70 \%$ to $80 \%$ have been observed in commercial fields of 'Crimson Sweet', 'Jubilee', and 'Sangria', which were among the more resistant cultivars in our tests. Growing more resistant cultivars, however, could help reduce losses to fruit blotch in some cases.

\section{Literature Cited}

Goth, R.W. and R.E. Webb. 1981. Resistance of commercial watermelon (Citrullus lanatus) to Pseudomonas pseudoalcaligenes subsp. citrulli. Plant Dis. 65:671-672.

Hopkins, D.L. 1989. Bacterial fruit blotch of watermelon: A new disease of watermelon, p. 74-75. In: C.E. Thomas (ed.). Proc. cucurbitaceae 89: Evaluation and enhancement of cucurbit germplasm symposium. 29 Nov.-2 Dec., 1989, Charleston, S.C.

Latin, R.X. and K.K. Rane. 1990. Bacterial fruit blotch of watermelon in Indiana. Plant Dis. 74:331.

Schaad, N.W., G. Sowell, Jr., R.W. Goth, R.R. Colwell, and R.E. Webb. 1978. Pseudomonas
Table 3. Watermelon cultivar resistance to bacterial fruit blotch in field tests at Leesburg, Fla.

\begin{tabular}{|c|c|c|c|}
\hline \multirow[b]{2}{*}{ Cultivar } & \multicolumn{2}{|c|}{ Fall $1989 z$} & \multirow{2}{*}{$\begin{array}{l}\text { spring } 1990 \\
\text { Infected } \\
\text { fruit }(\%) \mathrm{z}, \mathrm{w}\end{array}$} \\
\hline & $\begin{array}{l}\text { Foliar } \\
\text { ratingy }\end{array}$ & $\begin{array}{l}\text { Infected } \\
\text { fruit }(\%) \mathrm{x}\end{array}$ & \\
\hline Sugar Baby & 2.3 & 0 & $0 \mathrm{a}$ \\
\hline Jubilation & 1.7 & 50 & $3 \mathrm{a}$ \\
\hline Mirage & 1.0 & 25 & $6 \mathrm{ab}$ \\
\hline Calsweet & 2.3 & 33 & $7 \mathrm{ab}$ \\
\hline \multicolumn{4}{|l|}{ Crimson } \\
\hline Sweet & 2.0 & 0 & $10 \mathrm{ab}$ \\
\hline \multicolumn{4}{|l|}{ Crimson } \\
\hline Tide & 1.3 & 75 & $10 \mathrm{ab}$ \\
\hline Jubilee & 2.0 & 40 & $16 \mathrm{a}-\mathrm{c}$ \\
\hline Royal Sweet & 1.3 & 20 & $17 \mathrm{a}-\mathrm{c}$ \\
\hline Sangria & 2.7 & 0 & $17 \mathrm{a}-\mathrm{c}$ \\
\hline \multicolumn{4}{|l|}{ Royal } \\
\hline Windsor & 1.7 & 40 & $22 a-c$ \\
\hline Minilee & 2.0 & 67 & $28 \mathrm{a}-\mathrm{c}$ \\
\hline Early Jubilee & 2.0 & 0 & $38 \mathrm{bd}$ \\
\hline Royal Jubilee & 1.3 & 33 & $38 \mathrm{bd}$ \\
\hline Mickeylee & 2.3 & 83 & $39 \mathrm{bd}$ \\
\hline Charlee & 1.3 & 50 & $43 \mathrm{~cd}$ \\
\hline \multicolumn{4}{|l|}{ Charleston } \\
\hline Gray & 1.0 & 40 & $48 \mathrm{~cd}$ \\
\hline Prince Charles & 1.7 & 50 & $62 \mathrm{~d}$ \\
\hline \multicolumn{4}{|l|}{ Charleston } \\
\hline Grav 133 & 2.0 & 50 & $69 \mathrm{~d}$ \\
\hline
\end{tabular}

"Mean separation in columns by Duncan's multiple range test, $P=0.05$. Percentage of diseased fruit was analyzed after transformation to $\arcsin \mathrm{x}$. Foliar rating data and percent infected fruit data in Fall 1989 had no significant difference due to large variations among plots.

YDisease ratings were made 2 weeks after inoculation using a scale based on symptoms: $0=$ no symptoms, $1=$ less than $50 \%$ necrotic, $2=$ greater than $50 \%$ necrotic, and $3=$ greater than $50 \%$ necrotic plus spread to noninoculated foliage.

"Percentage of inoculated fruit that developed fruit blotch symptoms was determined 3 weeks after inoculation.

"One hill per plot was inoculated 3 weeks after planting and percentage of fruit that developed fruit blotch was determined at harvest.

pseudoalcaligenes subsp. citrulli subsp. nov. Intl. J. Systematic Bacteriol. 28:117-125.

Somodi, G.C., J.B. Jones, D.L. Hopkins, R.E. Stall, T.A. Kucharek, NC. Hodge, J.C. Watterson, and D. Randleas. 1991. Occurrence of a bacterial watermelon fruit blotch in Florida. Plant Dis. 75:1053-1056.

Sowell, G., Jr., and N.W. Schaad. 1979. Pseudomonas pseudoalcaligenes subsp. citrulli on watermelon: Seed transmission and resistance of plant introductions. Plant Dis. Rptr. 63:437441 .

Wall, G.C. and V.M. Santos. 1988. A new bacterial disease of watermelon in the Mariana Islands. Phytopathology 78: 1605. (Abstr.)

Wall, G.C. and V.M. Santos. 1989. A new bacterial disease of watermelon in the Mariana Islands. College of Arts and Sciences Res. Conf., Guam.

Webb, R.E. and R.W. Goth. 1965. A seedborne bacterium isolated from watermelon. Plant Dis. Rptr. 49:818-821.

Willems, A., M. Goor, S. Thielemans, M. Gillis, K Kersters, and J. De Ley. 1992. Transfer of several phytopathogenic Pseudomonas species to Acidovorax avenae subsp. avenae subsp. nov., comb. nov., Acidovorax avenae subsp. citrulli, Acidovorax avenae subsp. cattleyae, and Acidovoraxkonjaci. Intl. J. Systematic Bacteriol. 42:107-119. 